\title{
The dairy sector in the Azores Islands: possibilities and main constraints towards increased added value
}

\author{
André M. de Almeida ${ }^{1} \cdot$ Paula Alvarenga ${ }^{1} \cdot$ David Fangueiro $^{1}$ (B) \\ Received: 21 July 2020 / Accepted: 12 October 2020 / Published online: 24 November 2020 \\ (C) Springer Nature B.V. 2020
}

\begin{abstract}
The Azores archipelago is the most suitable region for dairy production in Portugal, representing $30 \%$ of the overall Portuguese dairy production. It has a production system characterized by an average milk yield of $6216 \mathrm{~kg} / \mathrm{cow} / \mathrm{year}$, and the predominance of pasture-based feeding and cows that have longer productive lives and lower incidence of metabolic/production diseases, such as acidosis or mastitis. The biggest problem with the Azores Islands dairy sector is the cost of transport, as the main markets are located in continental Portugal, over $1500 \mathrm{~km}$ away, and local dairy products have to compete with dairy products produced in mainland Portugal and in the rest of the European Union. Herein, the evolution of the dairy sector in the Azores Islands from 2007 to 2017 is presented. A SWOT (Strength, Weakness, Opportunity, and Threat) analysis was performed to find potential solutions to increase the value of the Azorean dairy sector. The most relevant solution considered was the valorization of the dairy production through three major aspects: higher milk quality, namely, better organoleptic properties; lower carbon footprint (not considering transport costs); and higher levels of animal welfare. Three examples are shown of such valorization: protected denomination of origin (PDO) cheeses, the "happy cows" program, and the production of an organic milk, from the Terceira Island. Some of these programs are relatively recent, so, it will be interesting to see how their sales and acceptance by consumers evolve, particularly under the current economic framework.
\end{abstract}

Keywords Cow milk $\cdot$ Cheese $\cdot$ Holstein $\cdot$ Dairy sector valorization $\cdot$ Protected denomination of origin (PDO)

\section{Introduction}

The Azores Islands (or Autonomous Region of the Azores) is a Portuguese autonomous region, with its own politicaladministrative status and government bodies (Polido et al. 2016). The archipelago is composed by nine volcanic islands located in the center of the North Atlantic Ocean, approximately $1500 \mathrm{~km}$ from Lisbon and $3900 \mathrm{~km}$ from New York City (Ng et al. 2019). Its nine islands are spread over $600 \mathrm{~km}$ and are divided into three groups in accordance with their geographical location: Eastern Group of São Miguel and Santa Maria; Central Group of Terceira, Graciosa, São Jorge, Pico, and Faial; and Western Group of Flores and Corvo (Fig. 1). It is an autonomous region of the Portuguese

David Fangueiro

dfangueiro@isa.ulisboa.pt

1 LEAF - Centro de Investigação em Agronomia, Alimentos, Ambiente e Paisagem, Instituto Superior de Agronomia, Universidade de Lisboa, Lisbon, Portugal
Republic, with a resident population of 242,846 inhabitants, according to the 2018 census data, representing $2.4 \%$ of the Portuguese population (INE 2020).

The Azores Islands has a mild temperate climate with abundant rainfall year-round (1930 mm; Massot 2015). Temperatures are always very stable, around $15-25^{\circ} \mathrm{C}$ most of the year. Such temperatures, combined with a permanent high relative humidity, create a unique climate that despite its temperate location has many characteristics of tropical and subtropical regions. Indeed, the Azores Islands is the only region producing tea (Camellia sinensis) in the European Union (EU). The region is also known for the growth of other (sub-) tropical crops such as pineapple (Ananas comosus), taro (Colocasia esculenta), sweet potato (Ipomoea batatas) or banana, and, more recently, coffee. Nevertheless, the main agricultural products are milk and dairy products for which the region has an exceptional aptitude for pasture-based dairy production, particularly within the context of that the Portuguese mainland that has chiefly a Mediterranean climate.

In the Azores, agriculture is one of the most important economic sectors and a relevant component of the regional 
Fig. 1 Map of the Azores Islands (design courtesy of Dr. Selma Pena, ISA/ULisboa)

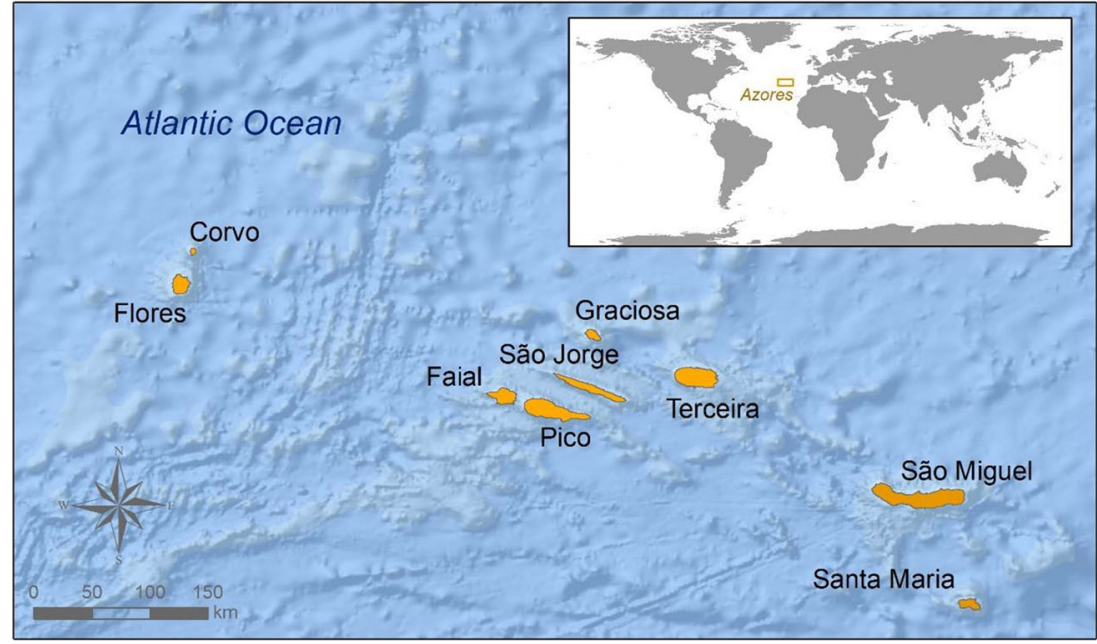

GDP (gross domestic product) (9.6\% in 2012) (Massot 2015). Agriculture and forestry are rather diverse, but dairy production is one of the most important sectors. According to the latest Land Occupation Report (COS.A 2018), approximately, half of the Azores territory is occupied by agriculture, $48.82 \%$, followed by forestry and natural and semi-natural vegetation, representing $42.60 \%$ of the Azores territory. Pasture is the most representative of the subclasses of land occupation, corresponding to $39.63 \%$, i.e., exceeding, by far, the other agricultural activities. This value represents a slight decrease relatively to 2007 , where pasture corresponded to $42.28 \%$ of the Azores land occupation (COS.A 2007).

Considering the agriculture production, banana is the most representative of the permanent cultures, with a production of $4657 \mathrm{t}$ in 2018 , followed by oranges (3708 t) and pineapple (948 t). As for the annual crops, corn or maize (used mostly for silage) is the most representative, with an annual production of $316,621 \mathrm{t}$ in 2018 , followed by potato (11,323 t) and beet (6550 t) (INE 2019).

Animal production is the most important sector, with dairy farming playing a major role, conditioned by the abovementioned importance of the pasture, in the context of land use, and forage production.

However, milk production in the Azores is relatively recent. Citrus orchards covered large parts of the island during the eighteenth and nineteenth centuries, and oranges were mainly exported to England as a remedy to scurvy (Langworthy 1987). A disease destroyed the viability of the citrus production, leading the Azorean farmers to turn their productions to a mixed-farming system, more based on high-value crops, such as tobacco and pineapple. Milk production only became significant during the first three decades of the twentieth century and grew after the World War I, when dairy processing companies from mainland Portugal started operations there, providing incentives to farmers to build herds. As a result, milk production increased from 45.5 million liters in 1945 to 250 million liters in 2014 (Langworthy 1987; Massot 2015).

Despite the importance of the Azores for the Portuguese milk production (30\% of total milk produced), most farms are small-sized and family owned, and a relevant part of them is the exclusive source of income for the farmer (Silva et al. 2018). With the problems that milk production is facing presently, due to the falling prices of milk on the producer, and the end of European milk quotas, it is important to look at the sector and find strategies to increase the value of the Azorean dairy products.

\section{Dairy production in the Azores: production system characterization}

\section{Dairy farms and milk production}

In 2017, total milk production in Portugal reached 1,863,440 t (Agricultural Statistics - 2018; INE 2019), a value similar to that of the 2007 milk production, albeit a decrease comparative to 2015 (Milk Production and Consumption Statistics 2015; INE 2016). This result was a consequence of two factors: on one hand, the new buying/selling agreements between producers and buyers of milk that were based on quantities well below those of 2015. On the other hand, the EU supported the reduction of milk production.

In contrast with the national average production, total milk production in the Azores region increased about $25 \%$ (from 507,000 to 629,000 t), from 2003 to 2015 (Milk Production and Consumption Statistics 2015; INE 2016). The Azores milk production represented $28.4 \%$ of the total Portuguese production in 2007 and 34\% in 2014 (Milk Production and Consumption Statistics 2015; INE 2016), highlighting the relevance of the Azores as a dairy region. However, milk production is predominantly concentrated in the São Miguel 
Island, which produced $89 \%$ of the Azorean production in 2017, followed by Terceira Island, with $11 \%$ (SREA 2019).

In the Azores, the dairy sector has a major importance to the regional production and economy, with the milk sector representing in 2017 about $30 \%$ of the gross regional agricultural production ( $30 \%$ of the farms/companies), a value which has been increasing since 2007 (Banco de Portugal 2019; SREA 2019). As seen in Fig. 2, the milk production in the Azores is also important to the national economy (Banco de Portugal 2019).

The size of farms and holdings in the Azores is quite variable with $50 \%$ of farms with less than 2 ha and $35 \%$ with 20 50 ha, leading to an average farm size of 8.9 ha per farm (Massot 2015). Moreover, the field area of farm is strongly atomized. In fact, a typical Azorean farm comprises different plots of lands of varied sizes that are rarely contiguous. This creates several problems to dairy farmers that have to move their stock and equipment (milking and feeding equipment) from plot to plot across public roads and paths. Consequently, the Azorean dairy farmers have to face several challenges that are inexistent in other regions or countries in the EU Atlantic area.

The Azores has a cattle inventory of 125,000 adult cows, and, of these, $73 \%$ are dairy cows (Agricultural Statistics 2018; INE 2019). The dairy farming system is characterized by the use of pasture and pasture rotation using HolsteinFriesian animals (Fig. 3). The majority of the milk however is produced in farms with small inventories (20-100 animals) and of small size (20-50 ha). The infrastructures are scarce even if the number of conventional dairy parlors has increased over the last years. Nevertheless, mobile milking machines are the predominant way of milking cows. The traditional dairy farms in the Azores used predominantly natural pastures,

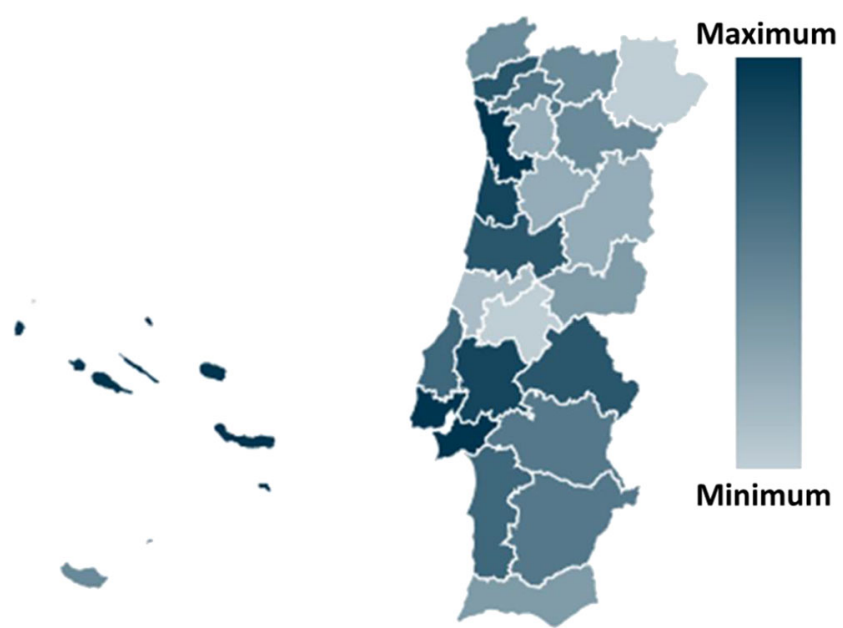

Fig. 2 Geographical distribution of the dairy farms considering their turnover (2017), represented by the blue scale. The Azores Islands has the largest value, corresponding to $15.1 \%$ of the total for the sector at the national level, and the second largest value considering the number of farms (14.0\% of the total) (Banco de Portugal 2019) albeit in recent years localized increases of production have been achieved by increasing the use of maize silage and concentrates. Generally, the Azores dairy production system was characterized by having low costs regarding tilling and fertilization, as well as the imports of animal feeds that was mostly produced locally. However, dairy production in some islands as São Miguel and Terceira has been intensified over the last years, specifically by importing concentrates and fertilizers to increase grass and maize silage production. Even though Holstein-Friesian animals are the predominant breed, the sector has not, in general, focused on high yield animals, and, in recent years, breeds more adapted to grazing and with a milk with high fat content, such as the Jersey, have been introduced on the islands (Galvão 2018). However, there are exceptions, where higher yield animals have become more frequent than in the past, particularly in the São Miguel and Terceira islands. Finally, and because it is chiefly pasture-based, the Azorean dairy sector has typically a low culling rate and associated replacement costs. In fact, the incidence of lameness and metabolic disorders, such as acidosis, is practically inexistent, and the average life expectance of a dairy cow range between 8 and 10 years.

Milk produced in the Azores, particularly in the São Miguel and Terceira islands, is traditionally collected through a network of collection points or deposits scattered across the islands and is then transported by truck to the main production plants where it is transformed. Nevertheless, all farmers investing in milking parlors have also acquired some milk tanks that allow valorizing the milk price in few cents. It is still to refer that it is a necessary condition (milk tank) to be integrated in some specific dairy added-value programs, such as the happy cows (Vacas Felizes) that will be discussed later.

Over the period 2007-2017 (INE 2018), the number of dairy farms in the Azores decreased by $19 \%$, and, simultaneously, a slight decrease of the number of dairy cows was observed in the region (3\%). In addition, the average number of dairy cows per farm increased by $36 \%$ from 25 cows in 2007 to 34 cows in 2016, indicating a growing concentration of dairy production. This concentration of the activity, among other factors, allowed a strong increase in dairy livestock productivity, from 5553 to $6934 \mathrm{~kg}$ milk/dairy cow/year. In the same decade (2007-2017; INE 2018), the amount of dairy farms with less than 20 cows decreased from 20 to $10 \%$, with a concomitant increase in medium size dairy farms, which are now the most representative in the region, increasing from a value of 26 in 2007 to $36 \%$ in 2016 . Moreover, dairy farms with more than 100 cows increased from 11 to $22 \%$ of the dairy farms, representing a tendency to inventory increase (INE 2019).

According to a study conducted by the Portuguese Institute of Statistics on the Portuguese dairy production and consumption (INE 2016), the Azores Islands was, in 2014, the most representative Portuguese region regarding economic 
Fig. 3 The traditional dairy production system of the São Miguel Island (Azores, Portugal). a Dairy cows on the paddock, $\mathbf{b}$ Mobile milking machine, c Area close to the milking machine on the paddock with water tanks and troughts, and $\mathbf{d}$ milk collecting point (deposit) for the Sete Cidades village
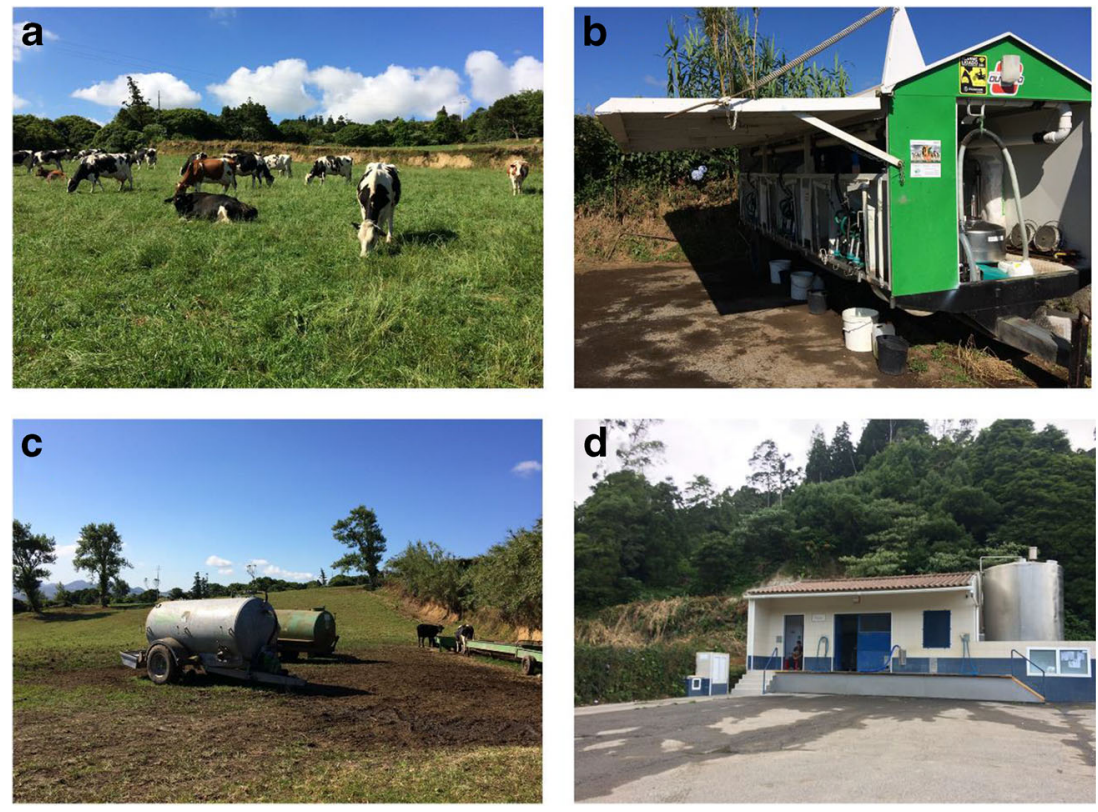

indicators of companies dedicated to animal production and dairy farming.

The labor costs in Azores are low and represent the second lowest value at the national level (Banco de Portugal 2019); this is caused by the low intensification of the production systems, with a considerable dependence on a pasture-free system for cows. Because of that, milk production per annual dairy working unit is higher than in mainland Portugal, where the production is more intensive, and characterized by higher dependence on the workforce (Banco de Portugal 2019). Other indicators of the low intensity of the dairy production in Azores are the low stocking rate (1.3 labor unit (LU)/ha of fodder in 2007) and the milk production (7.5 t/ha of fodder area, in 2007) (calculated values; Banco de Portugal 2019; SREA 2019). These values increased, due to the increase in productivity for the same agricultural area dedicated to fodder production.

The dairy production is very dependent on pasture even if the use of maize and grass silage tended to increase, namely, in São Miguel and Terceira islands. Supplementation with concentrate feed in dairy cows' intake is now a common practice although the amount of concentrate per cow is very variable. Indeed, this supplement is offered during milking, and therefore, those for farmers using a mobile milking parlor, the amount of concentrate is poorly controlled. In more intensive farms, concentrate supplementation is close to $2500-3000 \mathrm{~kg}$ concentrate/lactating cow/year, the equivalent to $8-10 \mathrm{~kg}$ concentrate/lactating cow/day and $3 \mathrm{~kg}$ concentrate/dry cow/ day. This concentrate, which corresponds to $16-20 \%$ of the total dairy cows feed intake, is the only purchased and imported feed. Grass represents approximately 35\% of feed intake. The improvement in the quality of grassland has allowed the recent increase in productivity.

\section{Dairy processors}

At the national level, the dairy processing companies are mostly micro, small, and medium size plants (Fig. 4a), being the large dairy plants located mainly in the Oporto region, followed by the Azores region (22.5\% of the total turnover) (Fig. 4b). In 2017, the dairy processing plants in the Azores corresponded to $11 \%$ of the total number of Portuguese dairy plants (including all kinds of milk), a number which has remained stable since 2007, and to a turnover of $24.7 \%$ (the second largest in the country) (Banco de Portugal 2019).

According to Banco de Portugal (2019), five large companies were operating in 2017 in São Miguel Island. One of them is based on a union of cooperatives specialized in different dairy products which operates only at the regional scale and collects $40-45 \%$ of the milk produced on the island. The second is a private enterprise operating at an international scale, specialized in different dairy products, collecting around $20-25 \%$ of the milk produced. The third is also a private company operating at a regional scale, specialized in different dairy products, but predominantly in powdered milk production, collecting around $15-20 \%$ of the milk produced. The fourth is a cooperative working at a regional level. It only collects $10-15 \%$ of the milk produced on the island without an associated dairy plant. The fifth is a private company, specialized in different dairy products commercialized by a multinational and collects around $5-10 \%$ of the milk produced.

The larger dairy enterprise operating at Terceira Island is a cooperative, specialized in different dairy products, operating only at the regional scale and collecting about $90 \%$ of the milk produced both in Terceira and in Graciosa (Central Group of islands). There is another recent private company that works in the Terceira Island that collects the remaining $10 \%$ of the 


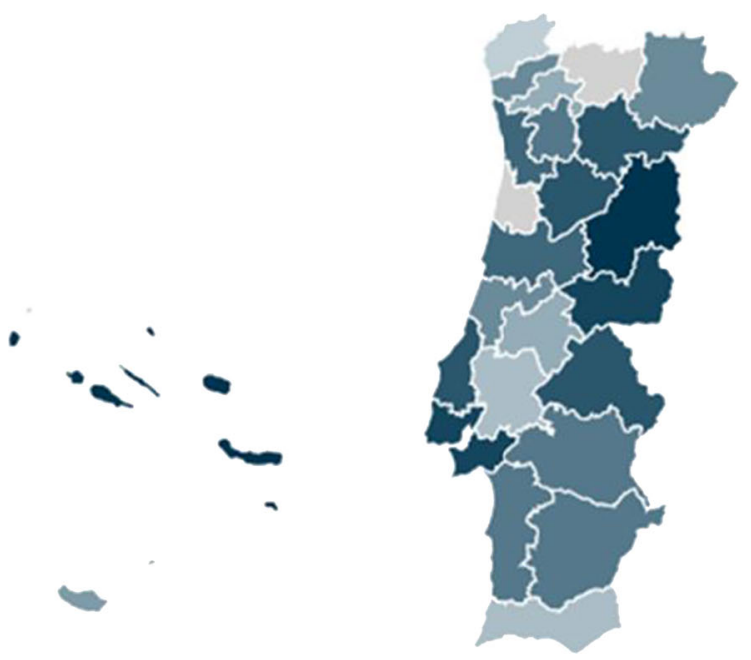

a

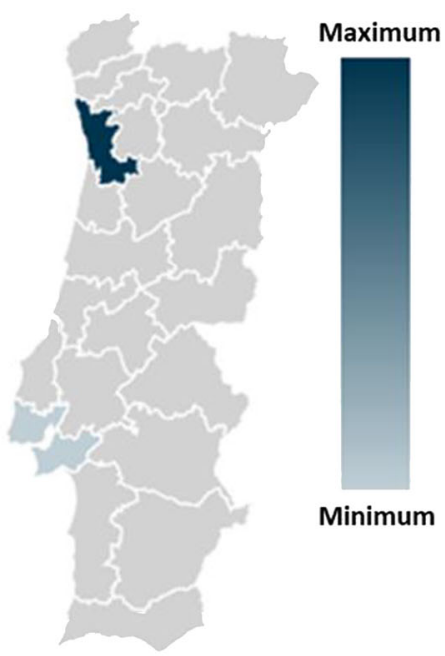

b

Fig. 4 Geographical distribution of the dairy processing plants considering their turnover (2017) represented by the blue scale: (a) micro, small, and medium size dairy plants and (b) large dairy plants (Banco de Portugal 2019)

milk production. The production from the other islands (Santa Maria, Pico, Faial, São Jorge, Flores, and Corvo) is negligible.

\section{Dairy products and characterization of dairy markets}

At the regional scale, the production of the different dairy products has increased from 2007 to 2017 (Fig. 5), with fresh milk being the main products, followed by cheese (SREA 2019). In the Azores, there are two types of cheeses with protected denomination of origin (PDO), produced in two different islands: São Jorge and Pico.

There is no on-farm processing, leading to two different players: dairy farms specialized in milk production and dairy plants specialized in dairy processing.

Azorean dairy produces milk that is transformed locally. The most important local product is UHT (ultra-high-temperature processing) milk. Other important products include butter and cheeses. In 2014, a total of 176,500 $t$ of dairy products were produced in the region, representing fresh milk and cheeses the $62 \%$ and the $18 \%$ of the total dairy production, respectively (SREA 2019).

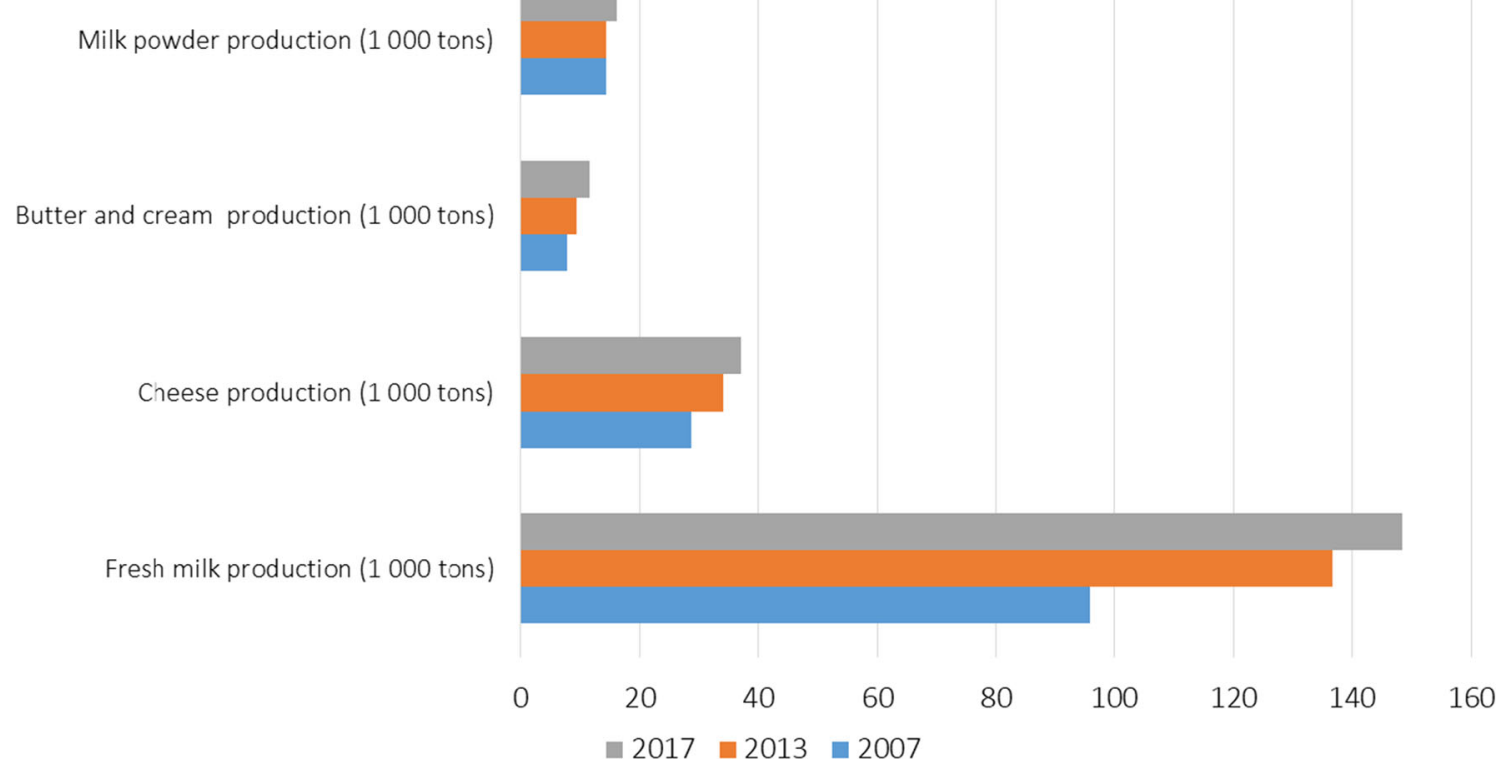

Fig. 5 Amounts of fresh milk, milk powder, cheese and butter, and cream produced in the Azores Islands in the 2007-2017 period (SREA 2019) 
According to data gathered on the Regional Statistics Service of the Azores (SREA 2019), the markets for the Azorean dairy products are located chiefly in mainland Portugal (75\% of the market) and the Azores Islands (15\% of the market). The degree of self-sufficiency in milk for consumption in Portugal is growing with a value of $112.5 \%$ in 2015 , while the self-sufficiency in butter achieved $100 \%$ in 1985 and remained in surplus since 1991. Contrariwise, Portugal lost its self-sufficiency in yogurts in 1990, having a deficit of 53\% in 2015. Even though the lack of official data relative to self-sufficiency for dairy products in Azores, considering the high milk production and low demographic density of the region, it is consensual that values of milk selfsufficiency should be over $100 \%$.

The above-mentioned context causes important difficulties to the Azorean dairy sector. If on one hand, production, investment, and labor costs tend to be generally low, on the other hand, the fact that major markets are in mainland Portugal increases prices significantly.

Furthermore, most of the Azorean dairy products are sold in the form of UHT milk, conventional butter, or Edam-type current cheeses (known in Portugal as Flamengo or Flemish), which causes additional competitiveness problems. In fact, and by producing standard milk and dairy products, the Azorean dairy sector is competing directly with dairy products from other Portuguese dairy regions (mainly from Northern Portugal) and the EU that tend to have lower production and transport costs. As such, the margins for Azorean dairy products and their market value are very low. It is, therefore, difficult for dairy farms to subsist and invest in such a context, raising economic sustainability issues for the whole region.

\section{Azores milk production in the framework of the Portuguese dairy sector}

Azores economy depends highly on the public sector, but also on traditional sectors, where livestock production and the related industries have a paramount importance (Polido et al. 2016). However, due to the vulnerability conditions of all small islands (i.e., small size, geographic isolation, narrow economic base, limited resources, ecosystem vulnerability to external ecological influences, relatively small population, with limited skills base), national and EU structural funds are central to the development of the region (Polido et al. 2016). The dairy sector is an example of this reality: the Regional Government strongly supports the milk production in Azores, namely, through subsidies fixed annually according to the regional budget, in order to offset the increased transport costs of raw materials and product (e.g., the subsidy was 6 euros/1000 L in 2018). In 2016, and according to the Azores Regional Government, the region received $46 \%$ of the European Commission funds allocated to Portugal to support milk producers. This demonstrates the importance of the Azores contribution to the sector at the national level. Furthermore, the premium was set at 45 euros per cow for the first 20 animals of each farm (Azores Government 2020).

The price of milk to be paid to the dairy farmers is fixed by the dairy industry, which sets the prices in agreement with the market demand for milk. The dairy market is very competitive, with a growing trend by the large supermarkets to offer low prices to the final consumer. The main consequence of such policies is a decrease of the margins of dairy companies with a direct impact on the price of milk to producers. Profit margins to production have declined in recent years, and there is a need to try to produce more milk at lower costs (increase the output). In the Azores, this has been achieved mainly with the improvement of the pasture quality and animal productivity based on improvement of the animal genetic and animal welfare and promoting an image of sustainability and respect for animal welfare.

Different operators are making some specific investments such as dryers to produce powdered milk, especially to operate in the periods where the regional production surpasses the market needs.

There are no production quotas imposed by the EU presently, but the dairy industries continue to impose quotas and accept to buy milk beyond the negotiated quota only at lower prices.

\section{SWOT (Strength, Weakness, Opportunity, and Threat) analysis of the dairy production in the Azores}

Considering the reality of the Azores dairy sector, it is possible to evaluate its strengths, weaknesses, opportunities, and threats in an attempt to indicate some solutions to boost the sector (Table 1). This evaluation was made considering some opinions from regional stakeholders, gathered in different formal and informal meetings.

The main weakness pointed out by dairy farmers and stakeholders is the remoteness of the Azores in the middle of the Atlantic Ocean. Indeed, it implies significant transport costs to and from the Azores, as well as a lower support from some dairy companies (e.g., equipment, machinery) not based in the Azores. However, such isolated location can be seen as a positive point in terms of sanitary conditions, since the ocean create a natural barrier and minimize the risk of disease spreading.

The decrease of dairy products consumption, combined with the restriction imposed by dairy processors to produce more milk, will motivate dairy farmers to adopt the "more is less" philosophy. Indeed, the milk quality is now more valued than the total amount produced. Therefore, it might be more profitable for farmers to decrease milk 
Table 1 SWOT analysis of the Azores dairy sector

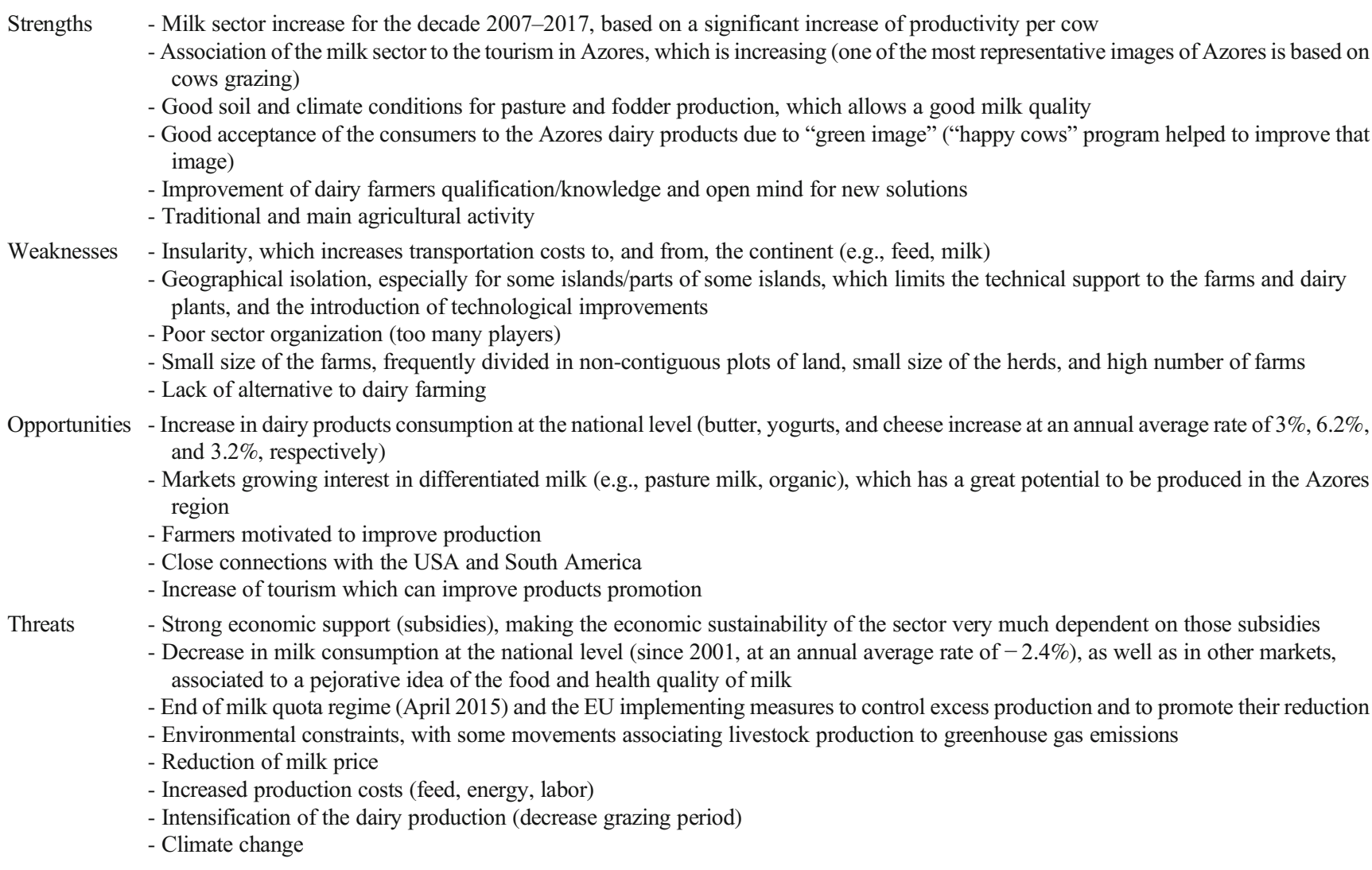

production by decreasing either the herd size or concentrate feed purchase. Despite the decreased number of farms, the availability of land is still scarce and a limiting factor, especially for young farmers. Indeed, prices associated to agricultural land renting or sales are subject to speculation, making impossible the establishment of new farms, or even the concentration of field plots.

The effect of climate change affects livestock production worldwide (Hernández-Castellano et al. 2019). Over the last years, precipitation has decreased in the Azores Islands, especially during summer, which has affected maize silage production. Such effect imposes a reflection on the viability of a more intensive dairy production in the Azores, based on maize and grass silage and concentrate feeds, by comparison to the traditional production system based on pastures.

Presently, the farmers working conditions are one of the main limiting factors to recruit specialized workers, or even to promote generational transfer of dairy farms. Indeed, the mobile milking parlor has the advantage of minimizing investments, infrastructures costs, and amortizations, but it implies spending many hours outdoors. Furthermore, farmers usually work more than $10 \mathrm{~h}$ per day and retain a small salary.

\section{Dairy products from the Azores: examples of increased added value}

Within the previously mentioned context and struggling to compete in the national dairy market, finding ways of increasing the value of the Azorean dairy products has been an important part of the regional dairy sector strategy in recent years.

Such strategy relies on several pillars. One of the most important is the high quality of Azorean dairy products. Despite that most of the dairy is sold without a real differentiation, the Azores brand is important to higher scale consumers in mainland Portugal, and just the fact that milk or cheese is produced in the Azores may have an immediate quality perception by consumers. This is particularly true for some Azorean dairy products that have a PDO certification, such as São Jorge and Pico cheeses that have very good organoleptic properties. Another pillar is tourism. Before the COVID-19 pandemic, the Azores received annually over 3 million hotel stays, and tourism is one of the most important economic activities in the region (Regional Statistics Service of the Azores - Tourism data; SREA 2019). Tourism is strongly associated to the green fields' landscape and, by consequence, to dairy cows, and this bucolic scenery has a very 
positive impact on visitors. Such impact may in turn be transferable to dairy products as well creating a positive perception among consumers.

Within this framework, and aiming a differentiation scheme that could somehow increase the added value of Azorean dairy products, several brands have exploited this concept. One of the most successful was the "happy cows" (Vacas Felizes) program which produces milk sold as "pasture milk." This is not a legal designation, so far, but it set a reference for production. The system is audited by a private certification company and includes 200 rules (e.g., cows must spend 365 days in pasture, animal welfare, low carbon footprint, among other requisites) that the producers have to follow in order to belong to the happy cows program. The company that developed this program uses that label to guarantee milk quality. The program was specifically designed to reinforce the positive image of the Azorean dairy production, with a special emphasis on the major consumer markets in continental Portugal, in their majority urban and with little contact with farming and animal production. The program pays an additional quality premium fee to farmers and has an emphasis on quality, and not competing, using low prices in order to attract consumers. Therefore, the "happy cows" program aimed to be an environmental responsible way of producing milk that, through high-quality milk, can be sold at a higher price targeting conscious middle-upper class consumers. Similar strategies can be found across Europe for instance in Brittany, in France, or the Alps, in Switzerland, France or Austria. These have proven to have a certain level of success, particularly in high-income countries. In the Azores and Portugal, the markets tend to be different from those in Northern Europe. Still, it will be interesting to assess the success of the program in the coming years.

A second interesting example of added value increase is the recently approved organic production milk (Leite Biológico) produced in the Terceira Island. In fact, this island and the Azores are pioneers in Portugal in the production of organic production seal for the milk. This production system pays an additional fee $(0.10 € /$ liter produced). It implies the reduction of number of cows per farm and certain feeding practices, with a special emphasis on the lack of supplementation and animals spending the entire year on pasture. Furthermore, it implies that pastures must be "converted" to organic production. Such "conversion" is defined by a minimum period of 2 years without the application of chemicals, such as herbicides and fertilizers. It features the slogan "Planet Earth deserved a milk like ours," and it places an emphasis on the ecological friendliness.

In certain aspects, it can be considered an analogous or even an improvement of the "happy cows program". Nevertheless, it has the organic agriculture seal, implying a different type of certification, and therefore more appealing to the ecological conscience of urban consumers. Presently, six farms are involved in this certification scheme, with a total volume of production of $3000 \mathrm{~L}$ per day. This milk was presented to consumers in mainland Portugal in November 2019, and it has received a good acceptance from the media. It is still relatively recent, compromising further conclusions. Nevertheless, it will be interesting to see how it evolves and if the consumers develop a preference for this product that is more expensive than most milk sold in Portugal.

The third example of differentiation is the PDO and local/ gourmet cheeses. The Azores has two PDO cheeses: São Jorge and Pico, from the islands with the same name. The latter has a very low level of production and can be considered virtually extinct. However, and regarding the PDO products from the Azores, the most successful story so far has been the S. Jorge PDO cheese (also known as Queijo da Ilha), being sold in most supermarkets in the continent, where it fetches high prices, being widely recognized by consumers.

It is the only PDO cheese exclusively manufactured with raw cow milk in Portugal. This traditional large-sized cheese possibly has important influences from Flanders, where some of the earlier settlers from the Azores originated in the sixteenth and seventeenth centuries, during the Iberian crown union. The S. Jorge cheese is traditionally sold in the continent in the form of slices, known as cunhas. As this cheese is very popular in mainland Portugal, if other cheeses traditionally produced could imitate its success, it would bring important benefits to the Azorean dairy sector. Such attempts have recently been made (see for instance the Queijo Velho from São Miguel Island). However, these initiatives would benefit from an institutional support from the Regional Government or from the agricultural associations as they could provide the technical and commercial support to develop the product.

There are also other cheeses produced locally in the Azores. These cheeses are cured, and some have a characteristic spicy flavor. All have relatively high prices, being in high demand by the gourmet market. However, most of them are difficult to find outside the region, except for Azorean fairs and Azores-specialized supermarkets and grocery stores. The major limitation is always the relatively low production volume for these cheeses and the associated transport costs, which makes difficult to compete with mainland PDO cheeses manufactured with either goat or sheep milks (or a mixture of the two species with bovine milk) as well as with Spanish, French, and Italian cheeses, well implanted in Portuguese distribution chains.

\section{Conclusions}

The Azores archipelago is one of the most suitable regions for dairy production in Portugal. It has a traditional production system that differs substantially from the rest of the country, highlighting lower milk yields compared with other Portuguese dairy regions, but in line with the EU average, 
and the predominance of pasture-based feeding cows that live longer and with a lower incidence of metabolic/production diseases such as acidosis or mastitis, but also small inventories, the reduced size of farms that cause consolidation issues. The biggest problems with Azorean dairy are transport costs, as the main markets are located in continental Portugal, over $1500 \mathrm{~km}$ away, and dairy products have to be transported by boat or plane but have to compete with dairy products produced in continental Portugal and the rest of the EU at lower prices. As such, the solution seems to be a valorization of the dairy production through three major avenues: higher milk quality, namely, better organoleptic properties; lower carbon footprint; and higher levels of animal welfare.

Acknowledgments The authors thank all Azorean stakeholders involved in the project, namely, Helder Dinis and Valter Melo from Associação Agrícola de São Miguel (Cooperativa União Agrícola, C.R.L.), José António Azevedo from Associação Agrícola da Ilha Terceira, Anselmo Pires from Associação de Jovens Agricultores Terceirenses, as well as Ana Fernandes from Milkpoint Portugal for their contributions. Authors finally thank Dr. Selma Pena (ISA/ULisboa) for the design of Fig. 1.

Funding This work was partially supported by the project Dairy4future (EAPA_304/2016 Interreg Atlantic Area) funded by the European Regional Development Fund through the Interreg Atlantic Area Program. The Authors acknowledge support from Fundação para a Ciência e a Tecnologia (Lisbon, Portugal), through the LEAF research center (UID/AGR/04129/2020).

\section{Compliance with ethical standards}

Conflict of interest The authors declare that they have no conflict of interest.

\section{References}

Azores Government, 2020. Press release (August 23, 2016): Azores receive $46 \%$ of funds allocated to Portugal to support milk producers. Regional Secretary for Agriculture and Forestry. Azorean Government Portal. http://www.azores.gov.pt/Portal/en/entidades/ sraf/noticias/Azores receive 46 of funds allocated to_Portugal to_support_milk_producers.htm. Accessed 7 May 2020.

Banco de Portugal, 2019. Eurosistema, Sector Tables, Lisboa. https:// www.bportugal.pt/QS/qsweb/Dashboards, Accessed 8 Jan 2019.

COS.A, 2007. Carta de Ocupação do Solo da Região Autónoma dos Açores, dezembro 2007. Secretaria Regional do Ambiente e do
Mar. Direcção Regional do Ordenamento do Território e dos Recursos Hídricos, http://ot.azores.gov.pt/store/inc/cosa2007/COS. A_RAA_Relatorio.pdf. Accessed 7 May 2020.

COS.A, 2018. Carta de Ocupação do Solo da Região Autónoma dos Açores. Direção Regional do Ambiente. Divisão do Ordenamento do Território, http://ot.azores.gov.pt/store/inc/cosa2018/relatorio/ Relatorio_COS.A_2018.pdf. Accessed 7 May 2020.

Galvão, M., 2018. Genética Jersey em São Miguel (Interview by Ruminantes to M. Galvão). Ruminantes. 29, 24-27. https://issuu. com/ruminantes/docs/ruminantes29/24 Accessed 29 Jan 2019.

Hernández-Castellano, L.E., Nally, J.E., Lindahl, J., Wanapat, M., Alhidary, I.A., Fangueiro, D., Grace, D., Ratto, M., Bambou, J.C., de Almeida, A.M., 2019. Dairy science and health in the tropics: challenges and opportunities for the next decades. Trop Anim Health Prod. 2019 Jun;51(5):1009-1017.

INE, 2016. Milk Production and Consumption Statistics 2015, Instituto Nacional de Estatística (Statistics Portugal). www.ine.pt. Accessed 7 Jan 2019.

INE, 2018. Agricultural Statistics - 2017. Instituto Nacional de Estatística (Statistics Portugal). https://www.ine.pt/. Accessed 7 Jan 2019.

INE, 2019. Agricultural Statistics - 2018. Instituto Nacional de Estatística (Statistics Portugal). https://www.ine.pt/. Accessed 7 May 2020.

INE, 2020. Demographic Statistics - 2018, Provisional Estimates of Resident Population. Instituto Nacional de Estatística (Statistics Portugal). https://www.ine.pt/. Accessed 7 May 2020.

Langworthy, M., 1987. Dairying in the Azores - Chapter 7. In: S.R. Pearson, F. Avillez, J.W. Bentley, T.J. Finan, R. Fox, T. Josling, M. Langworthy, E. Monke, and S. Tangermann (eds.), Portuguese Agriculture in Transition. Cornell University Press. Ithaca and London. 124-140.

Massot, A., 2015. A Agricultura do Arquipélago dos Açores - Estudo, Direcção-Geral de Políticas Internas, Departamento Temático B: Políticas Estruturais e de Coesão, União Europeia. https://www. europarl.europa.eu/RegData/etudes/STUD/2015/567667/IPOL STU(2015)567667_PT.pdf. Accessed 7 May 2020.

Ng, K., Borges, P., Phillips, M.R., Medeiros, A., and Calado, H., 2019. An integrated coastal vulnerability approach to small islands: The Azores case. Science of The Total Environment, 690, 1218-1227.

Polido, A., João, E., and Ramos, T.B., 2016. Strategic Environmental Assessment practices in European small islands: Insights from Azores and Orkney islands. Environmental Impact Assessment Review 57, 18-30.

Silva, E., Almeida, B., and Marta-Costa, A.A., 2018. Efficiency of the dairy farms: a study from the Azores (Portugal). European Countryside, 10 (4), 725-734.

SREA, 2019. Regional statistics on milk production, dairy production, and commercialization. Serviço Regional de Estatística dos Açores. https://srea.azores.gov.pt/. Accessed 7 Jan 2019.

Publisher's note Springer Nature remains neutral with regard to jurisdictional claims in published maps and institutional affiliations. 